\title{
EFFECT OF SUPPLEMENTAL FAT ON DRY MATTER INTAKE, NUTRIENT DIGESTIBILITY, MILK YIELD AND MILK COMPOSITION OF RUMINANTS
}

\author{
Haq Nawaz ${ }^{1}$ and Mubark Ali ${ }^{1, *}$ \\ ${ }^{1}$ Institute of Animal Sciences, University of Agriculture, Faisalabad-38040, Pakistan. \\ "Corresponding author's e-mail: drmubarak434@gmail.com
}

\begin{abstract}
Use of supplemental fat in the ration of ruminants is increasing. This review provides the recent knowledge on the effect of supplemental fat in ruminants' diets. In addition, the effect of supplemental fat on the nutrient intake, nutrient digestibility and body weight gain are also discussed. Research conducted on dairy cows shows that extra fat addition decreases dry matter intake (DMI) with the negative effect on digestibility. Gut peptides released in response to extra fat which have negative effect on DMI. This effect is not perceived in ewes and goats. The addition of fat in the diets of ruminants decreased the nutrient digestibility either due to protection of fiber from fermentation or toxic effect on cellulolytic microbes. The supplementation of fat is the good strategy for early lactating cows as fat addition increased the energy density. The trend to use supplemental fat is increasing because fats have 2.25 times more gross energy than carbohydrates.
\end{abstract}

Keywords: Supplemental fat, dry matter intake, nutrient digestibility, milk production, composition, ruminants

\section{INTRODUCTION}

Interest of supplementary fat in the ruminant's diet has currently increased. The aim to add fat sources in the ruminant diets is to reduce the medium chain saturated fatty acids and to increase the beneficial fatty acids (Lock and Bauman, 2004). Recommended feeding level for fat supplements is up to $3 \%$ of DMI (NRC, 2001). Staples (2006) reported that supplementing cows with fat can have many beneficial effects; usually increment in the energy density of the diet resulting in increased milk production and feed efficiency, which usually translates into more profit. Harvatine and Allen (2005) explained that less heat may be produced in the rumen during digestion of fat supplemented diets, as fatty acids are not digested in the rumen. Adding fat to the diet increases energy density without increasing rumen acid production, thus stabilizing ruminal $\mathrm{pH}$ relative to addition of grain. The supplementation of fat in the diets of cows negatively affects the DMI. This effect depends on the source of fat supplement. On the other hand, fat addition in ewes and goat diets did not show any negative effect on DMI. Addition of fat in diets increases energy density without either increasing starch content or sacrificing fiber intake consumption of fat results in less metabolic heat that must be dissipated; therefore, fat supplementation may by particularly beneficial when environmental temperature and humidity are high and cows are heat stressed. Feeding fat during heat stress may serve a dual function. Firstly, it lesser the heat load of animals because less heat is generated during digestion and metabolism of fat relative to protein and carbohydrate. Secondly, it increases energy density of the diet during periods when feed intake is likely to be depressed. Nutrient digestibility decreases by extra fat addition so hydrogenation process is required to enhance the melting point of fat or oil and decrease its solubility in ruminal fluid. Hydrogenated fats have rare negative effects on ruminal fermentation and nutrient digestion. Differences between fat supplements may be ratios of individual FA, levels of saturation, and the level to which the fat is protected from processing in the rumen (Allen, 2000).

Effect of supplemental fat on dry matter intake: In early lactation, dairy animals have a large requirement for energy but intake of energy may be limited by capacity for DMI. Addition of fat sources such as whole oilseeds or tallow in the diet may improve the energy status of high producing dairy animals but the net result depends on the effects of supplemental fat on DM intake, fatty acid digestibility and milk production. The DMI in dairy animals fed diets containing supplemental fat is affected by the source of supplemental fat, fatty acid composition, chain-length and degree of saturation of fatty acid, level of fat added and premixing treatment of supplemental fat. The addition of fat sources decreases the DMI but most of the research on ruminants has not shown the negative impacts on DMI (Table 1). Dietary fat inclusion leads to the reduction of DMI which may be the result of 1) increment of ruminating time with negative impacts on rumen digestion 2) delayed rumen emptying period by metabolic effect of long chain FA (Chilliard et al., 1993). Pantoja et al. (1994) reported decrement in organic matter intake combined with the decrease of rumen digestibility of neutral detergent fiber (NDF). It is may be due to the unsaturation of included fat. A parallel drop of $3.1 \mathrm{~kg} / \mathrm{d}$ in DMI reported by decreasing $10.1 \%$ in acid detergent fiber (ADF) digestibility (Martin et 
Table 1. Effect of different fat sources on dry matter intake in dairy ewes and goats, showed as difference with the control treatment.

\begin{tabular}{lllcc}
\hline Researcher & Fat source & $\begin{array}{l}\text { Animal } \\
\text { type }\end{array}$ & $\begin{array}{c}\text { Diet level } \\
(\% \text { DM) }\end{array}$ & $\begin{array}{c}\text { Dry matter } \\
\text { intake }(\mathbf{k g} / \mathbf{d})\end{array}$ \\
\hline Cieslak et al. $(2010)$ & Rapeseed oil & Ewes & 3.5 & +0.1 \\
Gómez-Cortés et al. $(2008)$ & Soybean oil & Ewes & 6.0 & +0.3 \\
Hervás et al. (2008) & Sunflower oil & Ewes & 6.0 & +0.1 \\
Casals et al. $(2006)$ & Calcium salts of palm oil fatty acids & Ewes & 4.2 & +0.2 \\
Bouattour et al. $(2008)$ & Soybean oil & Goats & 2.5 & 0.0 \\
Silva et al. $(2007)$ & Soybean oil & Goats & 4.5 & $-0.3^{*}$ \\
Ollier et al. $(2009)$ & Sunflower oil & Goats & 4.4 & +0.03 \\
Brown-Crowder et al. (2001) & Partially hydrogenated tallow & Goats & 4.5 & $+0.6^{*}$ \\
\hline
\end{tabular}

*Significant difference $\mathrm{p}<0.05$

Table 2. Effect of different fat sources on milk yield and milk composition in dairy ewes and goats, showed as difference with the control treatment.

\begin{tabular}{|c|c|c|c|c|c|c|}
\hline Researcher & Fat source & $\begin{array}{l}\text { Animal } \\
\text { type }\end{array}$ & $\begin{array}{c}\text { Diet level } \\
\text { (\% DM) }\end{array}$ & $\begin{array}{c}\text { Milk yield } \\
(\mathrm{kg} / \mathrm{d})\end{array}$ & $\begin{array}{c}\text { Milk fat } \\
(\mathrm{g} / \mathrm{kg})\end{array}$ & $\begin{array}{c}\text { Milk protein } \\
(\mathrm{g} / \mathrm{kg})\end{array}$ \\
\hline Cieslak et al. (2010) & Rapeseed oil & Ewes & 3.5 & $+0.1 *$ & -1.0 & -1.0 \\
\hline Gómez Cortés et al. (2008) & Soybean oil & Ewes & 6.0 & -0.0 & -3.2 & -5.4 \\
\hline Hervás et al. (2008) & Sunflower oil & Ewes & 6.0 & +0.1 & $+4.8^{*}$ & -3.0 \\
\hline Casals et al. (2006) & Ca salts of palm oil fatty acids & Ewes & 4.2 & -0.0 & $+23.9 *$ & 0.0 \\
\hline Bouattour et al. (2008) & Soybean oil & Goats & 2.5 & -0.1 & $+6.7 *$ & +0.1 \\
\hline Silva et al. (2007) & Soybean oil & Goats & 4.5 & -0.5 & +0.7 & +2.4 \\
\hline Ollier et al. (2009) & Sunflower oil & Goats & 4.4 & $-0.41 *$ & $+6.0 *$ & +0.4 \\
\hline Brown-Crowder et al. (2001) & Partially hydrogenated tallow & Goats & 4.5 & $+0.6 *$ & $+5.4 *$ & $+1.8 *$ \\
\hline
\end{tabular}

*Significant difference $\mathrm{p}<0.05$

al., 2008). This parallel drop is not clear in goats. Silva et al. (2007) compared the results of soybean oil and ground soybean inclusion with control diet. It was found that decrease in $10 \%$ NDF digestibility leads to $0.3 \mathrm{~kg} / \mathrm{d}$ reduction in DMI, although ground soybean lessened the DMI by exact amount without disturbing NDF digestibility. Abomasal infusions of free FA and oils determined the metabolic impact of fat source. Corresponding free FA, unsaturated fatty acids and triacylglycerol infusions decreased the DMI linearly (Litherland et al., 2005). Extra fat addition in diet decreased the DMI in ruminants but Perez-Alba et al. (1997) reported that the extra fat inclusion $(1.3 \mathrm{~g}$ extra fat $/ \mathrm{kg}$ live weight or $120 \mathrm{~g} / \mathrm{d}$ of calcium salts of olive oil FA) did not lower the DMI. Decline in the DMI is also observed by Brown-Crowder et al. (2001) with extra fat inclusion. The daily intake of fat decreased DMI in dairy animals (Litherland et al., 2005).

Effect of supplemental fat on nutrient digestibility: Published data on effect of fat supplementation on nutrient digestibility and body weight gain of ruminants is summarized in Table 3. Although it is beneficial to add fat to a diet to increase its energy density, liquid fat is adsorbed on particulate matter in the rumen and appears to either 'protect' fiber from fermentation or is toxic to cellulolytic organisms. Both effects reduce the digestibility of fiber in the rumen. Therefore, the process of hydrogenation is needed to increase the melting point of fat or oil and decrease its solubility in ruminal fluid. Hydrogenated fats have few negative effects on ruminal fermentation and digestion of nutrients. Digestibility of the dry matter (DM) and ether extract (EE) in lambs given diets with soybean oil was more and inclined to digest more crude protein (CP), but fat type did not affect the NDF digestibility (Foroozandeh $e t$ al., 2014). Piantoni et al. (2013) reported that palmitic acid enhanced the total tract digestibility of NDF (39.0 vs. $35.7 \%)$ and organic matter $(67.9$ vs. $66.2 \%)$ while the $\mathrm{CP}$ digestibility enhanced by $3.3 \%$. Brask et al. (2013) observed digestibility unaffected by rapeseed oil addition in the diet. Ground flaxseed enhanced the nutrient digestibility of fat by provision of more amount of oil in the rumen than ungrounded (Silva et al., 2007). Unsaturated fats are more digestible than saturated fats (Firkins and Eastridge, 1994), therefore hydrogenated palm oil had lower digestibility than calcium salts of palm fatty acids (Weiss and Wyatt, 2004). The inclusion of supplemental fat did not decrease or increase the nutrient digestibility (Benchaar et al., 2012).

Effect of supplemental fat on milk yield: In addition to maintenance requirements, lactating dairy animals need nutrients for milk and fat secretion. Production by these animals is adversely affected when energy intake is not 
Table 3. Effect of fat supplementation on nutrient digestibility and body weight gain of ruminants.

\begin{tabular}{|c|c|c|c|c|c|c|c|c|}
\hline \multirow[t]{2}{*}{ Researcher } & \multirow[t]{2}{*}{ Level (\%) } & \multirow[t]{2}{*}{ Fat source } & \multicolumn{6}{|c|}{ Digestibility (\%) } \\
\hline & & & DM & $\mathbf{O M}$ & NDF & $\mathbf{C P}$ & $\mathbf{E E}$ & ADF \\
\hline Foroozandeh et al. (2014) & 4.0 & Soybean oil & 63.1 & 66.6 & 45.9 & 64.1 & 59.8 & - \\
\hline Foroozandeh et al. (2014) & 4.0 & Ca-protected fat & 57.2 & 66.1 & 44.4 & 59.5 & 59.1 & - \\
\hline Piantoni et al. (2013) & 2.0 & Palmitic acid & 66.2 & 67.9 & 39.0 & 66.5 & - & - \\
\hline Brask et al. (2013) & 6.5 & Rapeseed oil & - & 71.9 & 61.1 & 64.5 & 58.0 & - \\
\hline Silva et al. (2007) & 2.0 & Ground flaxseed & 58.6 & 49.8 & 38.7 & 65.9 & 73.1 & 36.3 \\
\hline Weiss and Wyatt (2004) & 3.4 & Ca salts of palm fatty acids & 69.9 & 70.9 & 53.6 & 68.6 & - & - \\
\hline Weiss and Wyatt (2004) & 3.4 & Hydrogenated palm oil & 67.6 & 69.5 & 47.3 & 67.1 & - & - \\
\hline Benchaar et al. (2012) & 3.0 & Linseed oil & 64.0 & 65.4 & 46.8 & 65.8 & - & 49.8 \\
\hline Delobel et al. (2008) & 8.0 & Linseed oil & 66.5 & 70.2 & 53.0 & 79.1 & 83.7 & 50.1 \\
\hline
\end{tabular}

*DM (Dry matter), OM (Organic matter), CP (Crude protein), NDF (Neutral detergent fiber), EE (Ether extract), ADF (Acid detergent fiber).

sufficient to meet their production requirements. Production and persistency can be improved by addition of supplemental fat. Generally fat inclusion in diet increased the milk production clearly compared with control diet. This production increment is more with the higher degree of saturation, provision of encapsulated fats or calcium salts or palm oil. The relationship between extra fat inclusion and milk production is curvilinear in ruminants. To a certain level of fat inclusion in diet leads to increased milk production and after that level milk yield decrease (BrownCrowder et al., 2001; Gargouri et al., 2006). Increment in milk yield at lower fat addition is due the energy concentration of feed consumed. The reason of reduced milk production by extra fat inclusion is the combined negative effect on digestion and DMI. Milk yield decrement in studies by Martin et al. (2008) in cows and Silva et al. (2007) in goats by extra fat addition $(5.7 \%$ in the diets of former study and $4.5 \%$ in those of latter) compared with animals given control diets without fat inclusion was parallel with DMI and fibrous carbohydrate digestibility. The DMI and milk production was similar with control diet but $24 \%$ decrease in NDF digestibility observed when diet included with $5.1 \%$ of soybean oils, rapeseed or rice (Maia et al., 2006a; 2006b).

Effect of supplemental fat on milk composition: The impact of fat source on milk fat in cows depends on rumen digestion. This is ultimately related to the degree of saturation and fat sources protection by rumen microbes (Doreau and Chilliard, 1992). Regarding the protected fat, encapsulated plant oils increase milk fat content more than calcium salts of palm oil FA because latter increase milk production by dilution effect. Extruded oilseeds decrease milk fat content more than when treated and untreated in other ways. Gonthier et al. (2005) reported that $12.7 \%$ of extruded linseed in control diet reduced milk fat by $0.26 \%$ but fat content enhanced $0.20 \%$ and $0.14 \%$ when the same linseed was raw or micronized, respectively. The inclusion of various fat sources and origin (plants, calcium salts, animals, whole oilseeds) in the diets of the ewes and goats generally enhance the milk fat content (Table 2). Increasing inclusion level of fats in the diets of the ewes and goats resulted in linear increase of milk fat content (Rotunno et al., 1998; Brown-Crowder et al., 2001; Casals et al., 2006). At the beginning of lactation milk fat content is generally greater than end of the lactation. During the suckling period (up to 35 days of lactation) the milk fat $/ \mathrm{kg}$ content was found higher than in milking period (Pérez-Alba et al., 1997; Casals et al., 2006). Cow's milk fat content is negatively affected by non-protected fat sources. There are different metabolic and digestive causes which advanced to explain this negative effect. The reduction in short and medium chain FA is reported as limited milk secretion by Glasser $e t$ al. (2007), which may be due to decrease in volatile FA production in rumen and long chain FA has negative metabolic impact on mammary enzymes (Chilliard and Ferlay, 2004). Sampelayo et al. (2007) reported that this negative impact of non-protected fat is decreased by rumen transit in goats and ewes. Inclusion of fat in diet decreased the milk protein compared to the diet without fat in cows and ewes. This effect is not evident in goats (Table 2). After the peak lactation the negative impact is greater in cows and enhanced with the degree of unsaturation without regarding fat source (Wu and Huber, 1994; Schroeder et al., 2004). This protein content reduction is related to the reduction of milk casein when fat added diets were given. Reduced protein and casein content were observed by DePeters et al. (1987) when 3.5\% and 7\% extra fat added to diet compared to the control diet (1.2g protein and $0.9 \mathrm{~g}$ casein $/ \mathrm{kg}$ of milk). Milk casein, protein and casein/protein ratio also reduced by fat addition (Doreau and Chilliard, 1992). Reduction in protein and casein $(46.5 \mathrm{~g} / \mathrm{kg}$ and $35.4 \mathrm{~g} / \mathrm{kg}$ ) content of milk obtained by Zhang et al. (2006) compared to the control diet $(47.6 \mathrm{~g} / \mathrm{kg}$ and $36.7 \mathrm{~g} / \mathrm{kg})$ or diet fed with linseed $(47.1 \mathrm{~g} / \mathrm{kg}$ and $36.1 \mathrm{~g} / \mathrm{kg}$ ). In goats, content of milk are not negatively affected by level of inclusion, fat source or degree of unsaturation (Brown-Crowder et al., 2001; Fernandes et al., 2008). 
Conclusions: This review summarizes literature data on effect of supplementary fat on the DMI, nutrient digestibility, milk production and composition in ruminants. Addition of supplementary fat in the diet of ruminants causes reduction in the DMI. The decrease in DMI is related to the source of supplemental fat, fatty acid composition, chain-length and degree of saturation of fatty acid, level of fat added and pre-mixing treatment of supplemental fat. The digestibility of DM and crude fat increase whereas the digestibility of fiber decreases with the addition of fats in ruminant's diet. Unsaturated fats are more digestible than saturated. Supplementary fat shows positive effect on milk production. In rare cases, milk yield decreased by extra fat addition due to combined negative effect of DMI and nutrient digestibility. The data indicates that supplemental fat inclusion in diet increases the fat content in the milk while the milk protein decreases. The effect of supplementary fat on milk yield and composition depends on the type and source of supplementary fat.

\section{REFERENCES}

Allen, M.S. 2000. Effects of diet on short-term regulation of feed intake by lactating dairy cows. J. Dairy Sci. 836:1598-1624.

Benchaar, C., G.A. Romero-Perez, P.Y. Chouinard, F. Hassanat, M. Eugene, H.V. Petit and C. Côrtes. 2012. Supplementation of increasing amounts of linseed oil to dairy cows fed total mixed rations: Effects on digestion, ruminal fermentation characteristics, protozoal populations, and milk fatty acid composition. J. Dairy Sci. 95:4578-4590.

Bouattour, M.A., R. Casals, E. Albanell, X. Such and G. Caja. 2008. Feeding soybean oil to dairy goats increases conjugated linoleic acid in milk. J. Dairy Sci. 91:23992407.

Brask, M., P. Lund, M.R. Weisbjerg, A.L.F. Hellwing, M. Poulsen, M.K. Larsen and T. Hvelplund. 2013. Methane production and digestion of different physical forms of rapeseed as fat supplements in dairy cows. J. Dairy Sci. 96:2356-2365.

Brown-Crowder, I.E., S.P. Hart, M. Cameron, T. Sahlu and A.L. Goetsch. 2001. Effects of dietary tallow level on performance of Alpine does in early lactation. Small Ruminant Res. 39:233-241.

Casals, R.G., G. Caja, M.V. Pol, X. Such, E. Albanell, A. Gargouri and J. Casellas. 2006. Response of lactating dairy ewes to various levels of dietary calcium soaps of fatty acids. Anim Feed Sci. Technol. 131:312-332.

Chilliard, Y. and A. Ferlay. 2004. Dietary lipids and forages interactions on cow and goat milk fatty acid composition and sensory properties. J. Reprod. Nutr. Dev. 44:467-492.
Chilliard, Y., M. Doreau, G. Gagliostro and Y. Elmeddah. 1993. Addition de lipides protégés (encapsulés ou savons de calcium) à laration de vaches laitières. Effets sur les performances et la composition du lait. INRA Productions Animales 6:139-150.

Cieslak, A., J. Kowalczyk, M. Czauderna, A. Potkanski. and M. Szumacher-Strabel. 2010. Enhancing unsaturated fatty acids in ewe_s milk by feeding rapeseed or linseed oil. Czech J. Anim. Sci. 55:496-504.

Delobel, A., C. Fabry, N. Schoonheere, Istasse, L. and Hornick, J.L., 2008. Linseed oil supplementation in diet for horses: Effects on palatability and digestibility. Livest. Prod. Sci. 116:15-21.

DePeters, E.J., S.J. Taylor, C.M. Finley and T.R. Famula. 1987. Dietary fat and nitrogen composition of milk from lactating cows. J. Dairy Sci. 70:1192-1201.

Doreau, M. and Y. Chilliard. 1992. Influence d'une supplementation de la ration en lipides sur la qualite du lait chez la vache. INRA Productions Animales 5:103111.

Fernandes, M.F., R.C. Ramos, A. Nunes de Medeiros, R.G. Costa, M.A. Delmondes and A. Amorim. 2008. Características físico-químicas e perfil lipídico do leite de cabras mestiças Moxotó alimentadas com dietas suplementadas com óleo de semente de algodão ou de girassol. Rev. Bras. Zootecn. 37:703-710.

Firkins, J.L. and M.L. Eastridge. 1994. Assessment of the effects of iodine value on fatty acid digestibility, feed intake, and milk production. J. Dairy Sci. 77:2357-2366.

Foroozandeh, A.D., H.R. Amini, G.R. Ghalamkari, M. Shahzeydi and S.M. Nasrollahi. 2014. The effect of fat type and L-carnitine administration on growth, feed digestibility and blood metabolites of growing Afshari lambs. Livest. Prod. Sci. 164:67-71.

Gargouri, A., G. Caja, R. Casals and I. Mezghani. 2006. Lactational evaluation of effects of calcium soap of fatty acids on dairy ewes. Small Ruminant Res. 66:1-10.

Glasser, F., M. Doreau, A. Ferlay, J.J. Loor and Y. Chilliard. 2007. Milk fatty acids:mammary synthesis could limit transfer from duodenum in cows. Eur. J. Lipid Sci. Tech. 109:817-827.

Gómez-Cortés, P., P. Frutos, A.R. Mantecón, M. Juárez, M.A. de la Fuente and G. Hervás. 2008a. Milk production, conjugated linoleic acid content, and in vitro ruminal fermentation in response to high levels of soybean oil in dairy ewe diet. J. Dairy Sci. 91:15601569.

Gonthier, C., A.F. Mustafa, D.R. Ouellet, P.Y. Chouinard, R. Berthiaume and H.V. Petit. 2005. Feeding micronized and extruded flaxseed to dairy cows: Effects on blood parameters and milk fatty acid composition. J. Dairy Sci. 88:748-756.

Harvatine, K.J. and M.S. Allen. 2005. The effect of production level on feed intake, milk yield, and 
endocrine responses to two fatty acid supplements in lactating cows. J. Dairy Sci. 88:4018-4027.

Litherland, N.B., S. Thire, A.D. Beaulieu, C.K. Reynolds, J.A. Benson and J. K. Drackley. 2005. Dry matter intake is decreased more by abomasal infusion of unsaturated free fatty acids than by unsaturated triglycerides. J. Dairy Sci. 88:632-643.

Lock, A.L. and D.E. Bauman. 2004. Modifying milk fat composition of dairy cows to enhance fatty acids beneficial to human health. Eur. J. Lipid Sci. Tech. 39:1197-1206.

Maia, F.J., A.F. Branco, G.F. Mouro, S.M. Coneglian, G.T. dos Santos, T.F. Minella and K.C. Guimarães. 2006a. Inclusão de fontes de óleo na dieta de cabras em lactação: produção, composição e perfil dos ácidos graxos do leite. Rev. Bras. Zootecn. 35:1504-1513.

Maia, F.J., A.F. Branco, G.F. Mouro, S.M. Coneglian, G.T. Santos, T.F. Minella and K.C. Guimarães. 2006 b. Inclusão de fontes de óleo na dieta de cabras em lactação: digestibilidade dos nutrientes e parãmetros ruminais e sangüíneos. Rev. Bras. Zootecn. 35:14961503.

Martin, C., J. Rouel, J.P. Jouany, M. Doreau and Y. Chilliard. 2008. Methane output and diet digestibility in response to feeding dairy cows crude linseed, extruded linseed, or linseed oil. J. Anim. Sci. 86:2642-2650.

NRC. 2001. Nutrient Requirements of Dairy Cattle, $7^{\text {th }}$ Rev. Edn. National Research Council, National Academy of Science, Washington, DC.

Ollier, S., C. Leroux, A. de la Foye, L. Bernard, J. Rouel and Y. Chilliard. 2009. Whole intact rapeseeds or sunflower oil in high-forage or high-concentrate diets affects milk yield, milk composition, and mammary gene expression profile in goats. J. Dairy Sci. 92: 5544-5560.

Pantoja, J., J.L. Firkins, M.L. Eastridge and B.L. Hull. 1994. Effects of fat saturation and source of fiber on site of nutrient digestion and milk production by lactating dairy cows. J. Dairy Sci. 77:2341-2356.
Perez-Alba, L.M., S. De Souza Cavalcanti, M. Pérez Hernández, A. Martínez Marín and G. Fernández Marín. 1997. Calcium soaps of olive fatty acids in the diets of Manchega dairy ewes: effects on digestibility and production. J. Dairy Sci. 80:3316-3324.

Piantoni, P., A.L. Lock and M.S. Allen. 2013. Palimitic acid increased yields of milk and milk fat and nutrient digestibility across production level of lactating cows. J. Dairy Sci. 96:7143-7154.

Rotunno, T., A. Sevi, R. Di Caterina and A. Muscio. 1998. Effects of graded levels of dietary rumen-protected fat on milk characteristics of Comisana ewes. Small Ruminant Res. 30:137-145.

Sampelayo, M.R.S., Y. Chilliard, P. Schmidely and J. Boza. 2007. Influence of type of diet on the fat constituents of goat and sheep milk. Small Ruminant Res. 68:42-63.

Schroeder, G.F., G.A. Gagliostro, F. Bargo, J.E. Delahoy and L.D. Muller. 2004. Effects of fat supplementation on milk production and composition by dairy cows on pasture: a review. Livest. Prod. Sci. 86:1-18.

Silva, M.M.C., M.T. Rodrigues, R.H. Branco, C.A.F. Rodrigues, J.L.R. Sarmento, A.C. Queiroz and S.P. Silva. 2007. Suplementação delipídios em dietas para cabras em lactação: consumo e eficiência de utilização de nutrientes. Rev. Bras. Zootecn. 36:257-267.

Staples, C.R. 2006. Milk fat depression in dairy cows Influence of supplemental fats. Florida Ruminant Nutrition Symposium, Gainesville, FL.

Weiss, W.P. and D.J. Wyatt. 2004. Digestible energy values of diets with different fat supplements when fed to lactating dairy cows. J. Dairy Sci. 87:1446-1454.

Wu, Z. and J.T. Huber. 1994. Relationship between dietary fat supplementation and milk protein concentration in lactating cows: a review. Livest. Prod. Sci. 39:141-155.

Zhang, R.H., A.F. Mustafa and X. Zhao. 2006. Effects of feeding oilseeds rich in linoleic and linolenic fatty acids to lactating ewes on cheese yield and on fatty acid composition of milk and cheese. Anim. Feed Sci. Tech. 127:220-23. 